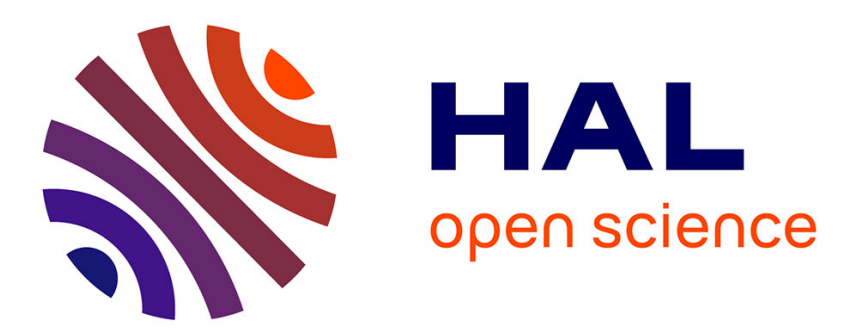

\title{
Vitrinite recycling: diagnostic criteria and reflectance changes during weathering and reburial.
}

Pierre Nzoussi - Mbassani, Yoann Copard, Jean-Robert Disnar

\section{To cite this version:}

Pierre Nzoussi - Mbassani, Yoann Copard, Jean-Robert Disnar. Vitrinite recycling: diagnostic criteria and reflectance changes during weathering and reburial.. International Journal of Coal Geology, 2005, 61, pp.223-239. 10.1016/j.coal.2004.08.002 . hal-00023485

\section{HAL Id: hal-00023485 \\ https://hal-insu.archives-ouvertes.fr/hal-00023485}

Submitted on 23 May 2006

HAL is a multi-disciplinary open access archive for the deposit and dissemination of scientific research documents, whether they are published or not. The documents may come from teaching and research institutions in France or abroad, or from public or private research centers.
L'archive ouverte pluridisciplinaire HAL, est destinée au dépôt et à la diffusion de documents scientifiques de niveau recherche, publiés ou non, émanant des établissements d'enseignement et de recherche français ou étrangers, des laboratoires publics ou privés. 


\title{
Vitrinite recycling: diagnostic criteria and reflectance changes during weathering and reburial
}

\author{
P. Nzoussi-Mbassani, Y. Copard and J.R. Disnar \\ Institut des Sciences de la Terre d'Orléans (ISTO- UMR 6113 du CNRS, Université \\ d'Orléans, Bâtiment de Géosciences, 45067 Orléans cedex 2, France
}

Keywords: Recycled vitrinite; Autochthonous vitrinite; Vitrinite reflectance; Senegalese basin; Ardèche margin; Weathering

\section{Abstract}

The aim of this study was first to review or even identify reliable diagnostic criteria to distinguish recycled and autochthonous vitrinite particles and, second, to examine and try to explain the impact of weathering and reburial on optical changes (reflectance) of recycled material. The work was based on indigenous and recycled particles of two sample sets from two wells drilled in the Senegalese margin basin and the Ardèche paleomargin (SE France), respectively. In addition to reflectance measurements, the studied samples have also been analysed by Rock-Eval pyrolysis. For both sample sets, hydrogen index $(\mathrm{HI})$ and oxygen index (OI) values suggest a type III organic matter of dominant terrestrial origin.

Two main diagnostic criteria appear particularly useful to identify indigenous and recycled vitrinite particles: the first is the clear genetic relationship between telinite and collotelinite; the second is the presence of pyrite framboid inclusions in indigenous vitrinite. The pyrite-vitrinite association illustrates the relationship between sulphate reduction, pyritisation, and in situ organic matter transformation through gelification process. However, application of both diagnostic criteria requires some additional information about depositional conditions (i.e., anoxicity) and thermal maturity of the studied samples. Weathering has no or only very limited effect on vitrinite reflectance. During their new burial history, recycled vitrinites follow a reflectance evolution path close to that of inertinites and thus appear as transitional materials between vitrinite and inertinite macerals. Consistently, this behaviour implies that recycled vitrinite reflectance changes during burial diagenesis do not solely depend on their chemical composition but, most probably too, on combined chemical and structural changes inherited from their past burial history and from the impact of weathering during their recycling stage. 


\section{Introduction}

Vitrinite reflectance is one of the most widely used parameters for thermal history reconstruction of sedimentary basins and maturation evaluation of source rocks (Dow, 1977, Alpern and Cheymol, 1978, Durand et al., 1986, Robert, 1985, Mukhopadhyay, 1994 and Suggate, 1998). According to a nonexhaustive literature review (Tissot and Welte, 1984, Murchison et al., 1985 and Durand et al., 1986), temperature and time are considered as the main factors influencing vitrinite reflectance increase according to first-order kinetics (Burnham and Sweeney, 1989). However, various limitations have been noticed on the value of this parameter as a rank indicator. Overall, two major problems can be encountered when using vitrinite reflectance as a tool for organic matter maturity assessment and/or for paleotemperature reconstruction. The first type of problem is that it is dependent on the intrinsic properties of vitrinite, resulting in an erroneous maturity assessment. There are several possible causes to such problems, for example: (i) palaeoenvironmental conditions of vitrinite formation (Kalkreuth, 1982, Price and Barker, 1985, Raymond and Murchison, 1991, Goodarzi et al., 1994 and Jimenez et al., 1994), (ii) the influence of the mineral matrix (Jones et al., 1971 and Pearson and Murchison, 1989), and (iii) hydrocarbon contamination (Iglesias et al., 2000). The second kind of problem simply arises from optical difficulties in properly identifying particles of collotelinite, maceral of the vitrinite group on which reflectance measurements are preferentially and commonly carried out (Alpern and Cheymol, 1978 and Robert, 1985). Although collotelinites are easily determined in coal formations, their determination is usually much more uncertain in dispersed organic matter (DOM), where they are usually mixed with anomalously higher-maturity vitrinite or vitrinite-like particles (Dow, 1977 and Barker, 1996). The latter particles (and others corresponding to other maceral groups) correspond to sedimentary organic material released by weathering of outcropping formations and then reintroduced in the supergene environment. There, if they are resistant enough to various degradation processes (biodegradation, oxidation) they can suffer in soils, rivers, and oceans, they can finally enter a new sedimentary cycle. The frequently observed mixture of autochthonous and recycled vitrinites (and other macerals) in sedimentary materials obviously witnesses the concomitant sedimentation of recent higher plant debris beginning their first burial history with recycled particles starting a new burial history.

Previous studies concerning those high-reflectance particles point out two fundamental questions. A key requirement, especially in order to circumvent the second one, is to have reliable identification criteria to discriminate recycled and autochthonous vitrinites (Dow and O'Connor, 1980, Teichmüller, 1982, Barker, 1996 and Malinconico, 2000). The poor agreement between reflectance data from different laboratories (Lo, 1992) clearly illustrates that this problem is still relevant today. Without adequate petrographic criteria, the optical identification is at least partly subjective and can then lead to erroneous maturity assessment. The second key question deals with the changes of the reflectance of recycled vitrinites provoked by the impact of the new thermal conditions they experience in addition to those they experienced during their recycling in supergene media (Dow, 1977 and Alpern and Cheymol, 1978). As a matter of fact, at least in a first approximation, the change in the optical characteristics of these recycled materials during their second burial 
history does not agree with the maximum paleotemperature concept developed for autochthonous material (Dow, 1977 and Alpern and Cheymol, 1978).

In this context, starting from the analysis of two sample sets taken from two different wells, the present study first aims to (re-)examine classical and possibly new criteria for distinguishing and identifying primary and secondary vitrinites. Then, in light of these observations and of previous findings, we reexamined and tried to explain the various changes that affect recycled vitrinites from their mobilisation after weathering of their host formation to their second burial site.

\section{Background and geological setting}

This study focuses on two different sedimentary series belonging to two different stratigraphic and geological contexts, but both deposited on a paleomargin where sedimentation was markedly influenced by terrestrial inputs. The first are CenomanoTuronian black shale deposits of the Senegal platform, and the second are Triassic sediments from the western paleomargin of the Tethys (Ardèche, France).

With its $340000 \mathrm{~km}^{2}$, the Senegal basin (Fig. 1) is the largest Meso-Cenozoic basin developed on the western Africa margin. It results from the breakup of Gondwana during Permo-Triassic times (Liger and Roussel, 1979 and Villeneuve and Da Rocha Arajou, 1984). Outcrops of sedimentary rocks are rare, and the geological knowledge is mainly based on subsurface data.
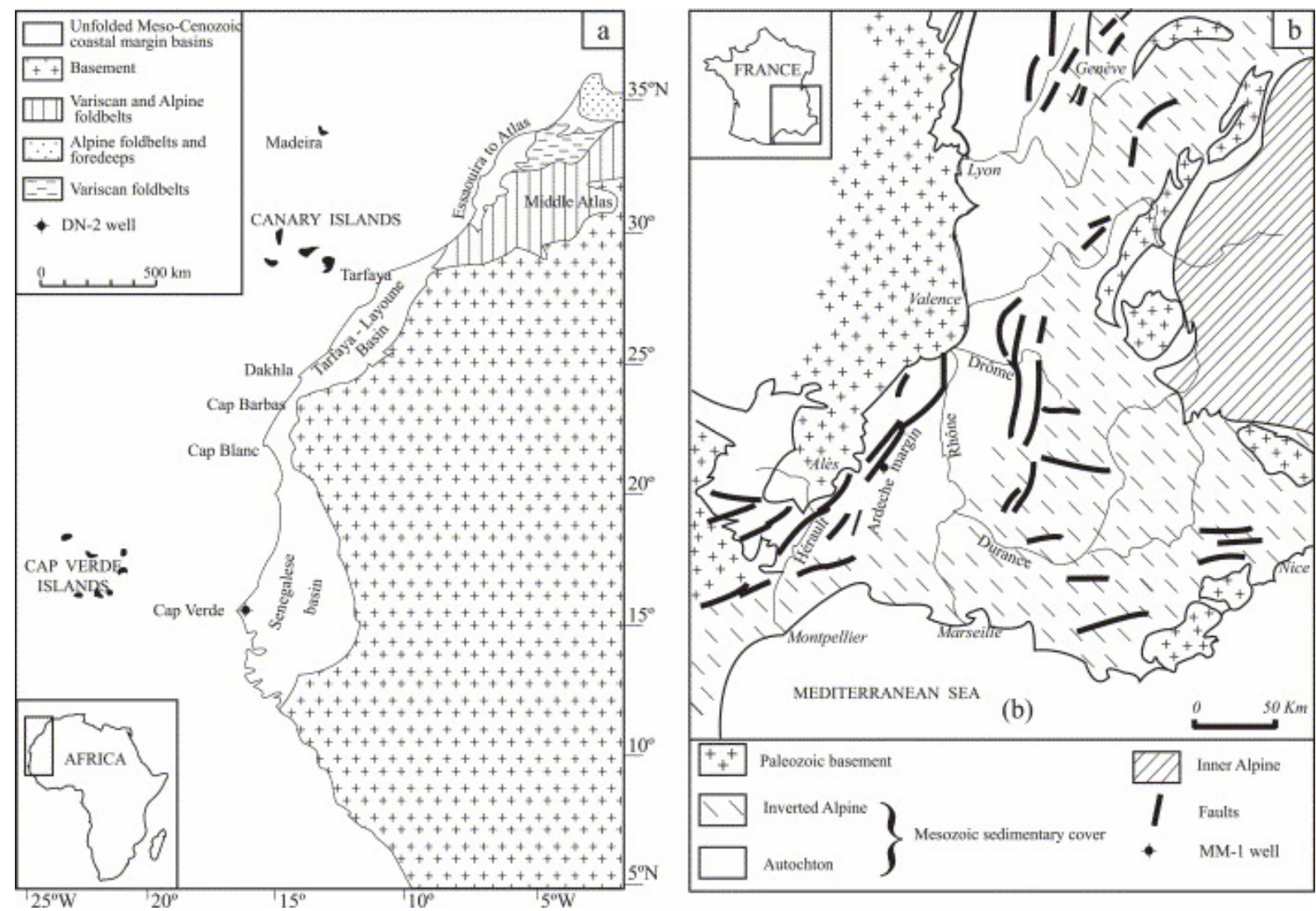

Fig. 1. (a) Location of the Senegalese basin and the DN-2 well in a map showing the geological setting of the west African margin. (b) Location map of the Ardèche area and MM-1 well in the southeastern France. 
The lateral distribution of various sediments in the Cenomano-Turonian formations reflects the interplay between fully marine, marginal marine, and littoral depositional processes (references in Nzoussi et al., 2003). Two major tectonic styles characterise the Senegalese basin: the prerift and synrift system dominated by transverse faults with formation of horst and graben and the postrift system dominated by major normal faults and a gravitational tectonic style. Lateral facies variations roughly show a regional parallelism with tectonic framework, suggesting a relation between sedimentation and contemporaneous tectonic activity.

The second studied series consists of Triassic sediments from the Morte Mérie well drilled in the Ardèche area (Fig. 1) in the south of France (Vinchon et al., 1996). Studied sediments are a complex series of green shales, sandstones, and anhydriterich clays deposited in lagoonal to marine environments during sea transgression across a peneplaned surface cutting across a Carboniferous and Permian basement. The basin progressively developed during Mesozoic times, and the sedimentary cover locally reached 9-km thickness. The southeast basin of France has experienced a complex geodynamic evolution and was affected by late Cretaceous and Tertiary deformations during Pyrenean and Alpine orogenies, with uplift and erosion and folding and partial basin inversion (Vinchon et al., 1996). Geological configuration of the studied part of the basin was mainly influenced by Uzer fault activity which separated this area in two compartments: the western Balazuc compartment and the eastern Uzer compartment in which the Morte Mérie well is located. During Liassic and Dogger, major tectonic activity affected this fault, resulting in a different subsidence history for both compartments (Elmi et al., 1991). The existence of major inconformity between Paleozoic and Triassic sediments suggest erosion and possible recycling of Palaeozoic sedimentary material during Mesozoic times, thus allowing favourable conditions for vitrinite recycling.

\section{Methods}

Thirty-eight samples of drill cuttings and core samples were collected from two wells, DN-2 and Morte Mérie-1 (MM-1), having penetrated Mesozoic formations in Senegal and in Ardèche France, respectively. Microscopic observations were performed with a Leica DMR XP microscope under white (reflected and transmitted) and ultraviolet light. Random vitrinite measurements ( $\mathrm{Rr}$ expressed in \%) were made following usual International Commission of Coal Petrology (ICCP) procedures on polished sections of concentrates of dispersed organic matter (DOM) using an oil immersion objective $(\times 50)$. The maceral composition of the dispersed organic matter (DOM) was determined on concentrates of dispersed organic matter (DOM) following the nomenclature of Stach et al. (1982) and ICCP (1971). Total organic carbon (TOC) contents (wt.\%), hydrogen index ( $\mathrm{Hl} ; \mathrm{mg} \mathrm{HC} \mathrm{g}^{-1} \mathrm{TOC}$ ), oxygen index (OI; $\mathrm{mg} \mathrm{CO}_{2} \mathrm{~g}^{-1}$ $\mathrm{TOC})$, Tmax $\left({ }^{\circ} \mathrm{C}\right)$ and petroleum potential $(\mathrm{PI})$ were determined by Rock-Eval 6 pyrolysis (Lafargue et al., 1998). The analyses were carried out on $100 \mathrm{mg}$ of crushed samples under standard conditions. 


\section{Results}

\subsection{Organic matter characterisation}

Geochemical data indicate low to very low organic carbon contents in both sedimentary series (Table 1 and Table 2). TOC values vary from $0.5 \%$ to $3.53 \%$ in DN-2 and do not exceed 2\% in MM-1 (Disnar et al., 1997). Except for some rare levels, $\mathrm{HI}$ is generally very low in $\mathrm{MM}-1$ (lower than $100 \mathrm{mg} \mathrm{HC} \mathrm{g}^{-1} \mathrm{TOC}$ ), while, in $\mathrm{DN}-2$, this parameter is higher than $100 \mathrm{mg} \mathrm{HC} \mathrm{g}^{-1} \mathrm{TOC}$. Tmax values vary from 435 to $445{ }^{\circ} \mathrm{C}$ in DN-2 and from 439 to 465 in MM-1, thus indicating that all studied samples have entered the oil window. MM-1 samples are more mature than DN-2 ones. As illustrated in Tmax vs. $\mathrm{HI}$ (Fig. 2) and HI vs. Ol diagrams (Fig. 2), OM belongs predominantly to type III. This latter statement combined with the presence of rather abundant maceral particles derived from higher plants allows us to assume that, in both study areas, the OM is mostly of terrestrial origin (Tissot and Welte, 1984). However, concerning MM-1, this assumption must be taken with caution because of the relatively high maturity level reached by the samples.

Table 1. : Rock-Eval data of DN-2 well

\begin{tabular}{|l|l|l|l|l|l|}
\hline Depth (m) & TOC (\%) & Tmax $\left({ }^{\circ} \mathbf{C}\right)$ & $\mathbf{S}_{\mathbf{2}}\left(\mathbf{m g ~ H C ~} \mathbf{~}-{ }^{-1} \mathbf{R}\right)$ & OI $\left(\mathbf{m g ~ O}_{2} \mathbf{~ g}^{-1} \mathbf{T O C}\right)$ & $\mathbf{H I}\left(\mathbf{m g ~ H C ~}^{-1} \mathbf{~ T O C}\right)$ \\
\hline 2014 & 0.33 & 435 & 0.33 & 88 & 100 \\
\hline 2022 & 0.62 & 436 & 0.59 & 75 & 95 \\
\hline 2026 & 0.54 & 437 & 0.35 & 83 & 65 \\
\hline 2034 & 0.54 & 438 & 0.16 & 20 & 30 \\
\hline 2096 & 0.39 & 439 & 0.21 & 70 & 54 \\
\hline 2102 & 1.3 & 438 & 2.5 & 20 & 192 \\
\hline 2200 & 0.62 & 438 & 0.59 & 65 & 95 \\
\hline 2260 & 3.06 & 439 & 9.5 & 22 & 310 \\
\hline 2270 & 2.88 & 443 & 11.25 & 24 & 390 \\
\hline 2282 & 3.17 & 445 & 9.52 & 18 & 300 \\
\hline 2310 & 2.85 & 443 & 8.61 & 25 & 302 \\
\hline 2350 & 2.7 & 444 & 2.7 & 18 & 100 \\
\hline 2406 & 2.22 & 443 & 2.45 & 22 & 110 \\
\hline 2430 & 3.19 & 447 & 8.95 & 20 & 280 \\
\hline 2434 & 2.02 & 445 & 4.25 & 16 & 210 \\
\hline 2444 & 0.91 & 447 & 0.28 & 34 & 147 \\
\hline 2446 & 3.53 & 445 & 6.12 & 25 & 173 \\
\hline 2566 & 0.57 & 450 & 0.37 & 45 & 65 \\
\hline
\end{tabular}




\begin{tabular}{|l|l|l|l|l|l|}
\hline Depth (m) & TOC (\%) & Tmax $\left({ }^{\circ} \mathbf{C}\right)$ & $\mathbf{S}_{\mathbf{2}}\left(\mathbf{m g ~ H C ~ g}^{-1} \mathrm{R}\right)$ & Ol $\left(\mathbf{m g ~ O}_{\mathbf{2}} \mathbf{g}^{-1} \mathbf{T O C}\right)$ & $\mathbf{H I}\left(\mathrm{mg} \mathrm{HC} \mathrm{g}^{-1} \mathbf{T O C}\right)$ \\
\hline 2586 & 0.9 & 449 & 0.75 & 16 & 83 \\
\hline 2598 & 0.66 & 448 & 0.99 & 20 & 150 \\
\hline 2602 & 1.25 & 447 & 2.56 & 18 & 205 \\
\hline 2608 & 1.5 & 448 & 2.3 & 22 & 153 \\
\hline 2626 & 2.28 & 444 & 6.98 & 20 & 305 \\
\hline 2632 & 3.09 & 440 & 9.76 & 30 & 315 \\
\hline 2641 & 2.98 & 448 & 8.96 & 24 & 300 \\
\hline 2646 & 2.24 & 450 & 6.97 & 18 & 311 \\
\hline 2649 & 2.04 & 450 & 6.45 & 18 & 316 \\
\hline
\end{tabular}
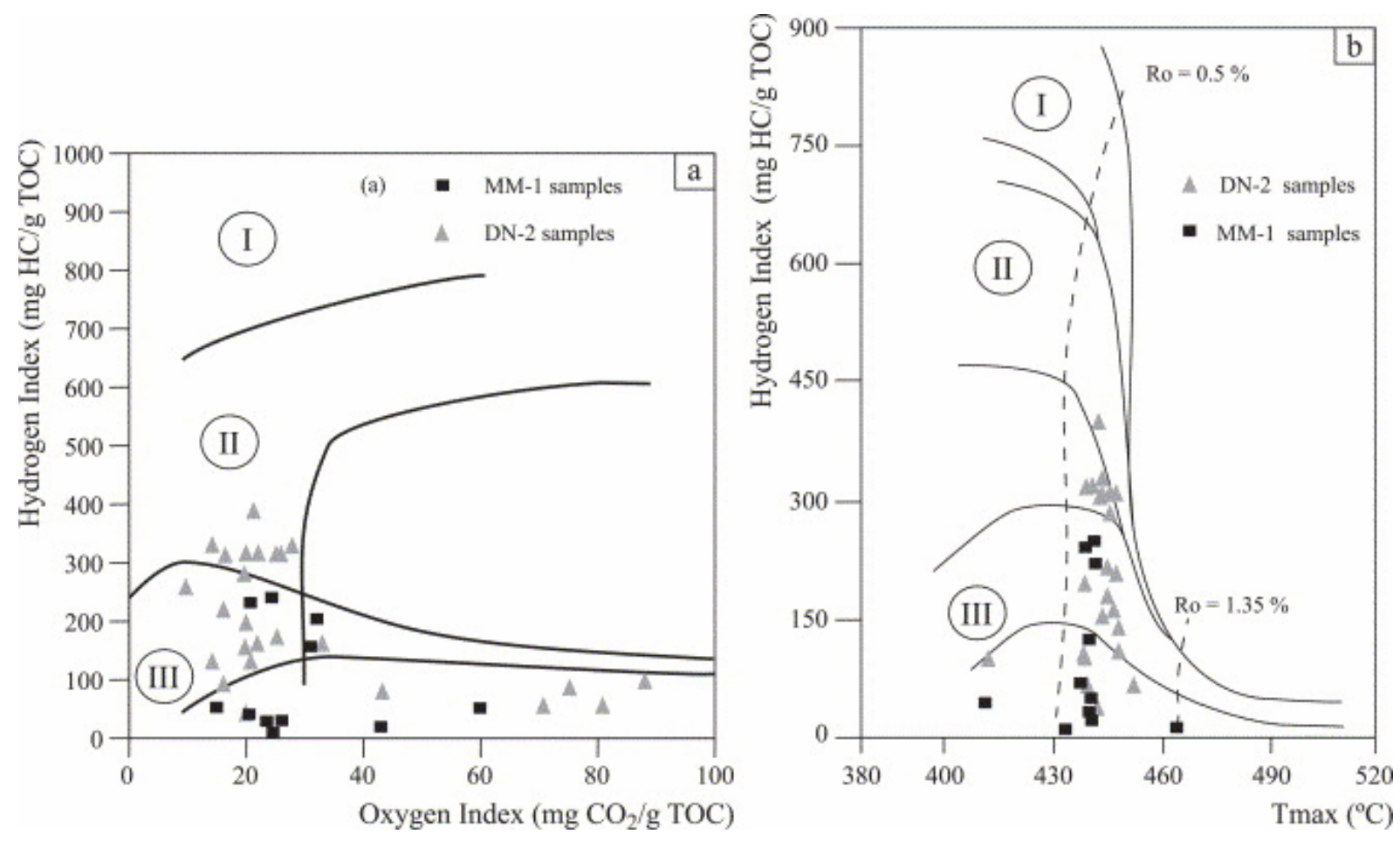

Fig. 2. Location of the studied samples in a hydrogen index vs. oxygen index diagram (a) and hydrogen index (HI) vs. Rock-Eval Tmax diagram (b).

Maceral analyses (Table 3 and Table 4) reveal that the sedimentary OM is dominated by vitrinite particles in both wells. Different subgroups of this maceral have been recorded particularly in DN-2. 
Table 2. : Rock-Eval data of MM-1 well

\begin{tabular}{|c|c|c|c|c|c|}
\hline Depth (m) & TOC (\%) & $\operatorname{Tmax}\left({ }^{\circ} \mathrm{C}\right)$ & $\mathrm{S}_{2}\left(\mathrm{mg} \mathrm{HC} \mathrm{g}^{-1} \mathrm{R}\right)$ & $\mathrm{OI}\left(\mathrm{mg} \mathrm{O}_{2} \mathrm{~g}^{-1} \mathrm{TOC}\right)$ & $\mathrm{HI}\left(\mathrm{mg} \mathrm{HC} \mathrm{g}{ }^{-1} \mathrm{TOC}\right)$ \\
\hline 20.52 & 0.74 & 439 & 0.28 & 25 & 37 \\
\hline 37.74 & 0.48 & 437 & 0.22 & 15 & 45 \\
\hline 61.86 & 0.34 & 439 & 0.1 & 20 & 29 \\
\hline 76.56 & 0.3 & 413 & 0.13 & 60 & 43 \\
\hline 92.2 & 1 & 439 & 1.09 & 30 & 109 \\
\hline 109.13 & 1.95 & 437 & 1.17 & 25 & 236 \\
\hline 116.42 & 1.18 & 438 & 2.79 & 30 & 217 \\
\hline 139.63 & 0.28 & 434 & 0.61 & 25 & 4 \\
\hline 147.66 & 0.22 & 438 & 0.01 & 25 & 244 \\
\hline 298.85 & 0.27 & 465 & 0.04 & 45 & 14 \\
\hline 300.67 & 0.52 & 440 & 0.15 & 25 & 28 \\
\hline
\end{tabular}

In this well, vitrinite has been found to be dominant, constituting $44 \%$ and $69 \%$ of total macerals. A small portion of the vitrinite is telinite, but the majority is made of collotelinite particles. Telinite is present in the shallower levels examined but disappears progressively with depth. The relative proportions of recycled particles (see diagnostic criteria here after) vary between $5 \%$ and $20 \%$. The liptinite content, which is less than $15 \%$, is dominated by resinite particles. Inertinite (10\% to $25 \%$ ) is primarily inertodetrinite particles which can be considered as "recycled" debris of the inertinite maceral group. As in DN-2, maceral composition in $\mathrm{MM}-1$ is dominated by vitrinite particles. The proportions of recycled particles here are higher than in the previous well and vary from $30 \%$ to $45 \%$, while autochthonous particles rarely exceed $50 \%$. Inertinite particles are very minor $(\leq 10 \%)$ and also dominated by inertodetrinite. Contrary to DN-2, telinite and liptinite were not observed in MM-1 samples. 
Table 3. : Results of maceral analysis of DN-2 well

\begin{tabular}{|c|c|c|c|c|c|c|c|}
\hline $\begin{array}{l}\text { Depth } \\
\text { (m) }\end{array}$ & Desmocollinite & Telinite & Collotelinite & $\begin{array}{l}\text { Recycled } \\
\text { vitrinite }\end{array}$ & Inertodetrinite & Fusinite & Exinite \\
\hline 2014 & 0.00 & 24 & 32.21 & 7.48 & 34.58 & 0.00 & 1.87 \\
\hline 2022 & 0.00 & 17 & 46.12 & 12.77 & 22.70 & 0.71 & 0.71 \\
\hline 2026 & 0.00 & 12 & 40.48 & 14.85 & 32.67 & 0.00 & 0.00 \\
\hline 2034 & 0.00 & 26 & 36.99 & 8.24 & 28.02 & 1.10 & 0.00 \\
\hline 2096 & 0.00 & 9 & 39.55 & 13.77 & 35.51 & 0.00 & 2.17 \\
\hline 2102 & 2.72 & 14 & 34.30 & 17.69 & 25.17 & 0.00 & 6.12 \\
\hline 2200 & 0.00 & 7 & 40.79 & 18.38 & 31.62 & 0.74 & 1.47 \\
\hline 2260 & 0.00 & 10 & 37.52 & 8.51 & 36.88 & 0.00 & 7.09 \\
\hline 2270 & 0.00 & 6 & 43.62 & 20.16 & 26.14 & 1.31 & 3.27 \\
\hline 2282 & 0.00 & 6 & 57.69 & 6.37 & 24.20 & 5.10 & 0.64 \\
\hline 2310 & 0.00 & 0 & 56.58 & 9.87 & 32.24 & 0.00 & 1.32 \\
\hline 2350 & 0.00 & 7 & 54.11 & 6.94 & 25.00 & 2.78 & 4.17 \\
\hline 2406 & 0.00 & 0 & 50.41 & 9.76 & 39.02 & 0.81 & 0.00 \\
\hline 2430 & 0.00 & 1 & 62.84 & 3.98 & 29.55 & 0.00 & 2.27 \\
\hline 2434 & 0.00 & 0 & 62.58 & 6.75 & 20.25 & 1.23 & 9.20 \\
\hline 2444 & 0.00 & 4 & 61.24 & 7.93 & 19.51 & 0.00 & 7.32 \\
\hline 2446 & 0.00 & 1 & 61.95 & 5.95 & 29.73 & 1.08 & 0.54 \\
\hline 2566 & 0.00 & 1 & 61.78 & 5.63 & 22.54 & 0.00 & 9.15 \\
\hline 2586 & 0.00 & 2 & 55.75 & 8.19 & 28.65 & 0.58 & 5.26 \\
\hline 2598 & 2.94 & 0 & 58.24 & 5.88 & 27.06 & 1.18 & 4.71 \\
\hline 2602 & 0.00 & 2 & 58.51 & 4.46 & 35.03 & 0.00 & 0.00 \\
\hline 2608 & 0.00 & 0 & 69.18 & 6.16 & 23.97 & 0.68 & 0.00 \\
\hline 2626 & 0.00 & 1 & 58.78 & 5.03 & 32.40 & 0.00 & 2.79 \\
\hline 2632 & 10.92 & 0 & 58.05 & 7.47 & 22.41 & 1.15 & 0.00 \\
\hline 2641 & 0.00 & 0 & 55.15 & 13.24 & 30.88 & 0.00 & 0.74 \\
\hline 2646 & 0.00 & 0 & 49.71 & 14.45 & 30.06 & 0.00 & 5.78 \\
\hline 2649 & 0.00 & 0 & 59.68 & 6.45 & 30.65 & 0.54 & 2.69 \\
\hline
\end{tabular}

Collotelinite and inertodetrinite constitute the predominant maceral. 
Table 4. : Results of maceral analysis of MM-1 well

\begin{tabular}{|l|l|l|l|l|l|l|l|}
\hline $\begin{array}{l}\text { Depth } \\
(\mathbf{m})\end{array}$ & Desmocollinite & Telinite & Collotelinite & $\begin{array}{l}\text { Recycled } \\
\text { vitrinite }\end{array}$ & Inertodetrinite & Fusinite & Exinite \\
\hline 20.52 & 0 & 0 & 53 & 39 & 8 & 0 & 0 \\
\hline 37.74 & 0 & 0 & 57 & 40 & 3 & 0 & 0 \\
\hline 61.86 & 0 & 0 & 62.55 & 34 & 3.45 & 0 & 0 \\
\hline 76.56 & 0 & 0 & 51.42 & 39 & 9.58 & 0 & 0 \\
\hline 92.2 & 0 & 0 & 59.14 & 30 & 10.86 & 0 & 0 \\
\hline 109.13 & 0 & 0 & 50.99 & 42 & 7.01 & 0 & 0 \\
\hline 116.42 & 0 & 0 & 49.35 & 45 & 5.65 & 0 & 0 \\
\hline 139.63 & 0 & 0 & 54.12 & 37 & 8.88 & 0 & 0 \\
\hline 147.66 & 0 & 0 & 50.75 & 44.02 & 5.23 & 0 & 0 \\
\hline 298.85 & 0 & 0 & 59 & 39.6 & 1.4 & 0 & 0 \\
\hline 300.67 & 0 & 0 & 52.56 & 41 & 6.44 & 0 & 0 \\
\hline
\end{tabular}

Collotelinite and recycled vitrinite constitute the predominant macerals.

\subsection{Petrographic diagnostic criteria}

Different diagnostic criteria are used to distinguish autochthonous from recycled vitrinites. From the morphological point of view, autochthonous vitrinite is mainly characterised by angular forms and a generally rather large size (more than $50 \mu \mathrm{m}$; Lo, 1992). This angular shape and rather large size certainly exclude a strong fragmentation due to long transportation. However, those purely morphologic features cannot solely be taken as a reliable identification criterion. They need to be coupled with other observations, and, here, two main criteria are used. A first criterion is the presence of telinite and associated collotelinite. It is well known that telinite is a category of vitrinite with well-preserved cellular structures (Stach et al., 1982 and Scott, 2002). Such structures witness in situ degradation of original lignocellulosic tissues. In the samples located at the top of Cenomano-Turonian series (immaturemature limit), where telinite coexists with collotelinite, there is undeniable similarity in size and form between both particle types. The progressive disappearance of the former ones at depth suggests their progressive transformation into collotelinite during coalification (ICCP, 1998). This clear relationship and even affiliation between telinite and collotelinite supports an autochthonous origin for vitrinite particles.

Autochthonous vitrinite often contains pyrite framboid inclusions (Fig. 3). This is never the case in particles of recycled organic material (Fig. 3). Pyrite is an indicator of anoxia in the sediment deposition medium. Such conditions are required for the gelification of lignocellulosic debris to proceed and so to allow vitrinite formation. 

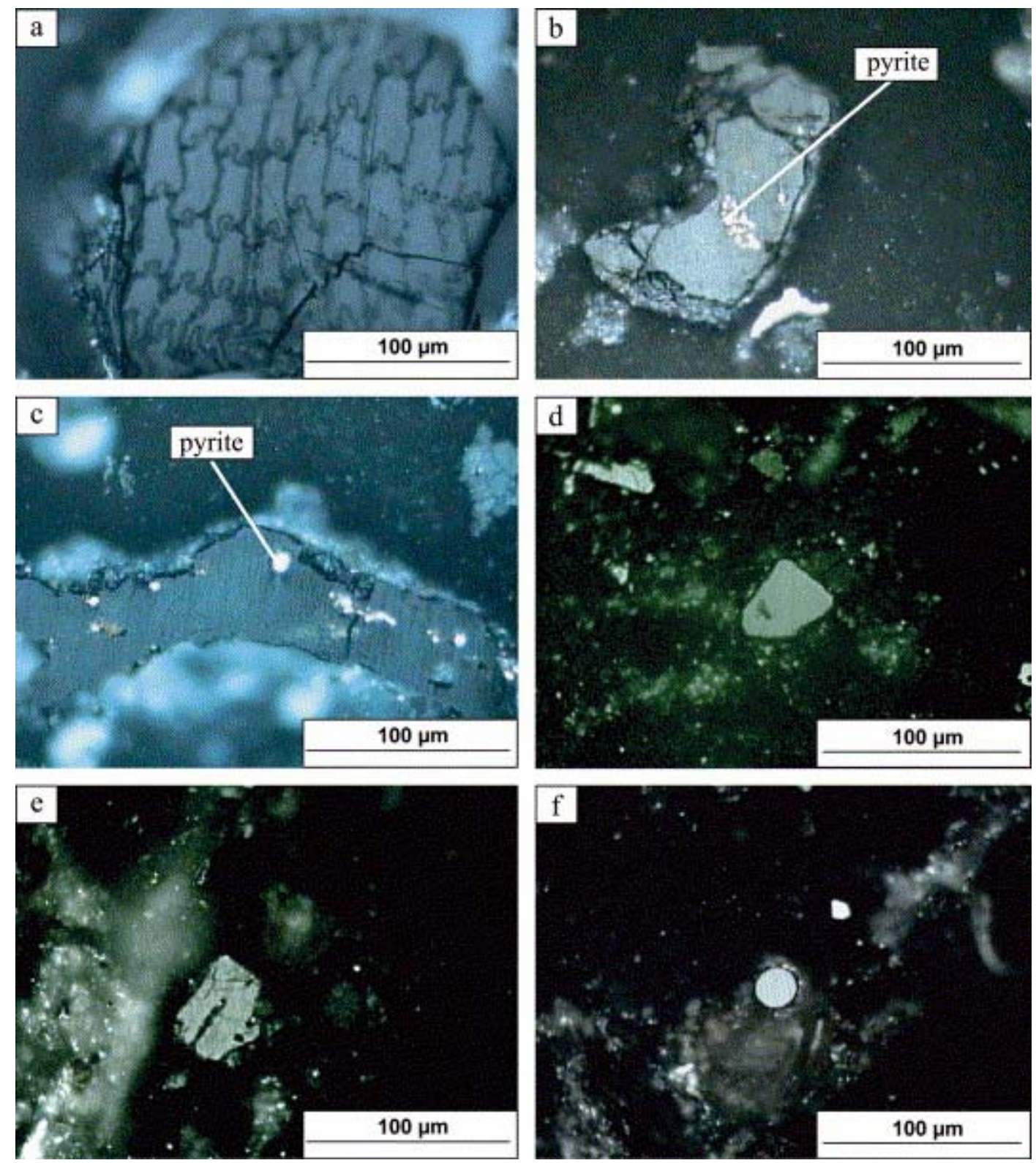

Fig. 3. Optical microphotographs of indigenous and recycled vitrinite (incident white light): (a) telinite particle; (b) and (c) angular collotelinite particles with inclusions of framboidal pyrite; (d) and (e) small and subrounded particles; (f) rounded particle. Note the absence of pyrite framboids in recycled particles.

Thus, the pyrite-vitrinite association supports a relationship between sulphate reduction, pyritisation, and gelification processes during early diagenesis. Nevertheless, the presence of pyrite inclusion was not clearly observed in vitrinite particles from the MM-1 well, thus clearly illustrating the fact that the presence of sulphide minerals is not an absolute criterion of primary vitrinite identification. Another classical feature of recycled vitrinites is the small size and rounded form of the particles that is attributable to long transport impact. In order to support the two last criteria mentioned above, reflectance evolution for autochthonous were correlated to Tmax data (see below for details). 


\subsection{Reflectance measurements}

\subsubsection{DN-2 well}

The number of reflectance measurements made on individual samples varied between 52 and 117. Reflectance histograms (Fig. 4) globally show trimodal distributions, thus suggesting the presence of three principal populations of vitrinitelike particles. The first population $\left(P_{1}\right)$, which presents the lower $R_{0}$ value, is minor. Generally, low reflectance may suggest different materials such as perhydrogenous vitrinite, debris from caving or drilling mud, or liptinite (Barker, 1996 and Dow and O'Connor, 1980). Because the reflectance of these particles practically does not change with depth, they certainly correspond to an artefact, this later one being either due to pollution by lignite debris used during drilling operations or to caving. This interpretation conforms to DN-2 samples mainly composed of cuttings. The second population $\left(P_{2}\right)$ represents the previously characterised autochthonous vitrinite which shows reflectance values between $0.50 \%$ to $0.90 \%$ (Fig. 5). The good correlation between these reflectance values and those of Tmax supports the autochthonous origin of this group of particles. The third population $\left(P_{3}\right)$ of particles, with $R_{0}$ values varying between $0.8 \%$ and $1.3 \%$, corresponds to recycled material (Fig. 5). The reflectance profile slope gives an indication on the vitrinite transformation rate (Dow, 1977). Fig. 5 clearly indicates that, despite the same thermal context, the transformation rate of both recycled and autochthonous material is different. This later point will be further discussed below.
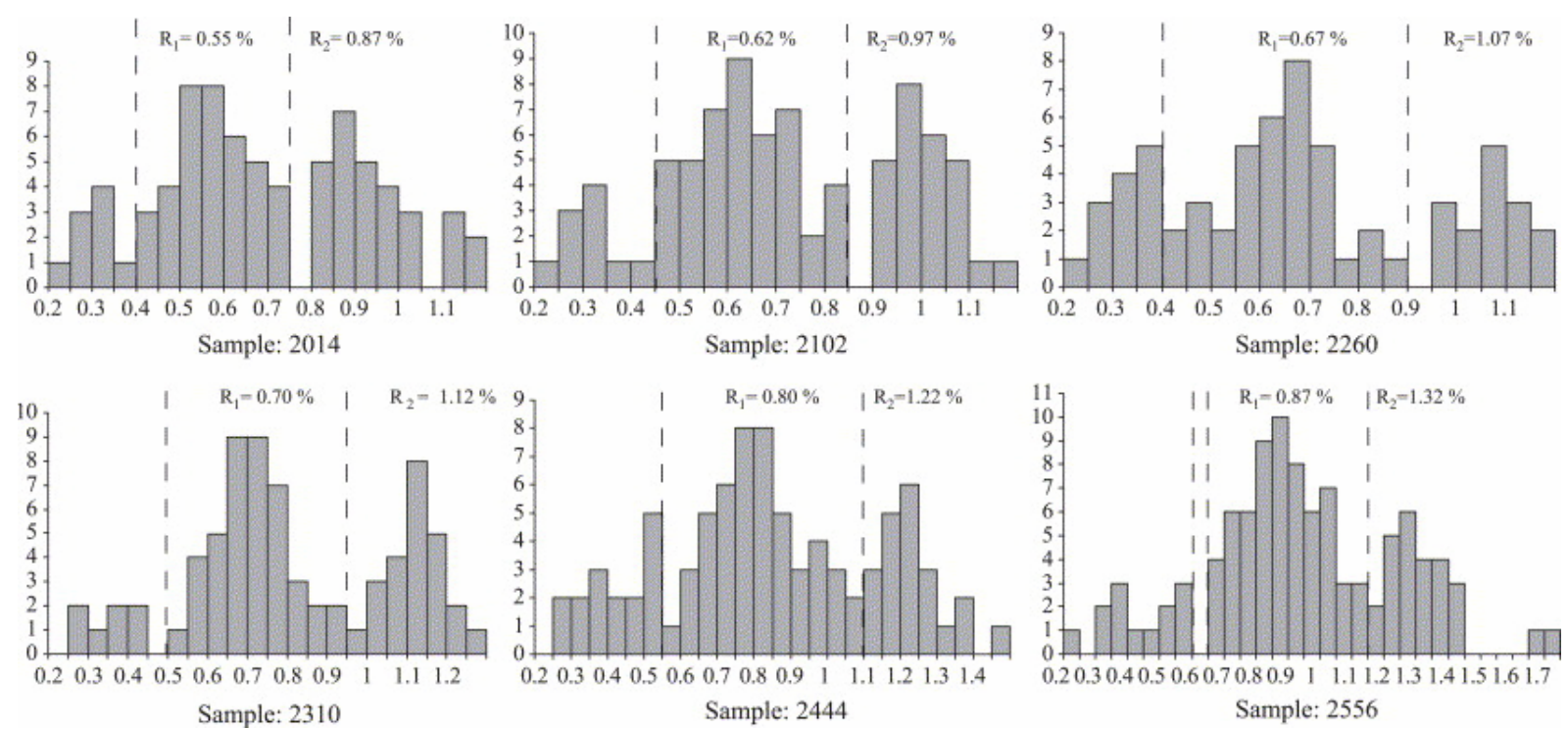

Fig. 4. Reflectance histograms indicating three vitrinite populations in DN-2 samples. 

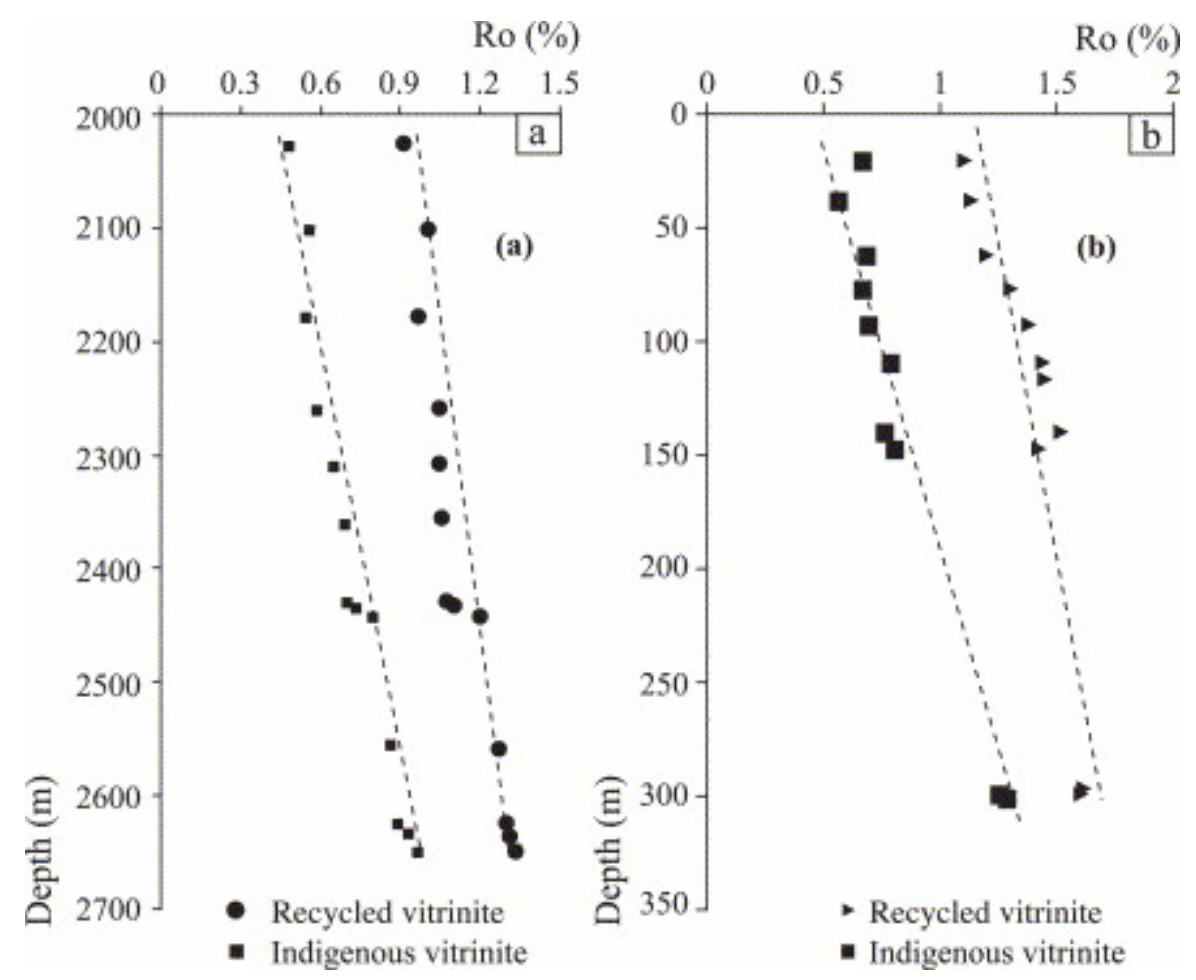

Fig. 5. Plot of indigenous and recycled vitrinite reflectance data against depth in the DN-2 and MM-1 wells. Note the subparallel evolution with depth for both profiles with increasing maturity.

\subsection{2. $\mathrm{MM}-1$ well}

The number of reflectance measurements made on individual samples varies between 41 and 102. Vitrinite reflectance histograms suggest two main populations (Fig. 6). There is a similarity between reflectance evolution observed in DN-2 and $\mathrm{MM}-1$ wells. In the latter borehole, the normal maturity trend corresponding to autochthonous particles is depicted by reflectance values increasing from 0.67 to 1.09 between 20.25 and $300.67 \mathrm{~m}$ and from $1.1 \%$ to $1.69 \%$ for recycled particles between the same levels (Fig. 5). However, in MM-1 contrary to DN-2, Tmax data do not show a good correlation with autochthonous vitrinite reflectance values. In addition, the reflectance profile slope also suggests that the autochthonous particles obey to a much higher transformation rate than recycled particles. Overall, the results from both wells clearly suggest that, in spite of the same thermal heat, autochthonous and recycled particles do not follow the same evolution trend. 

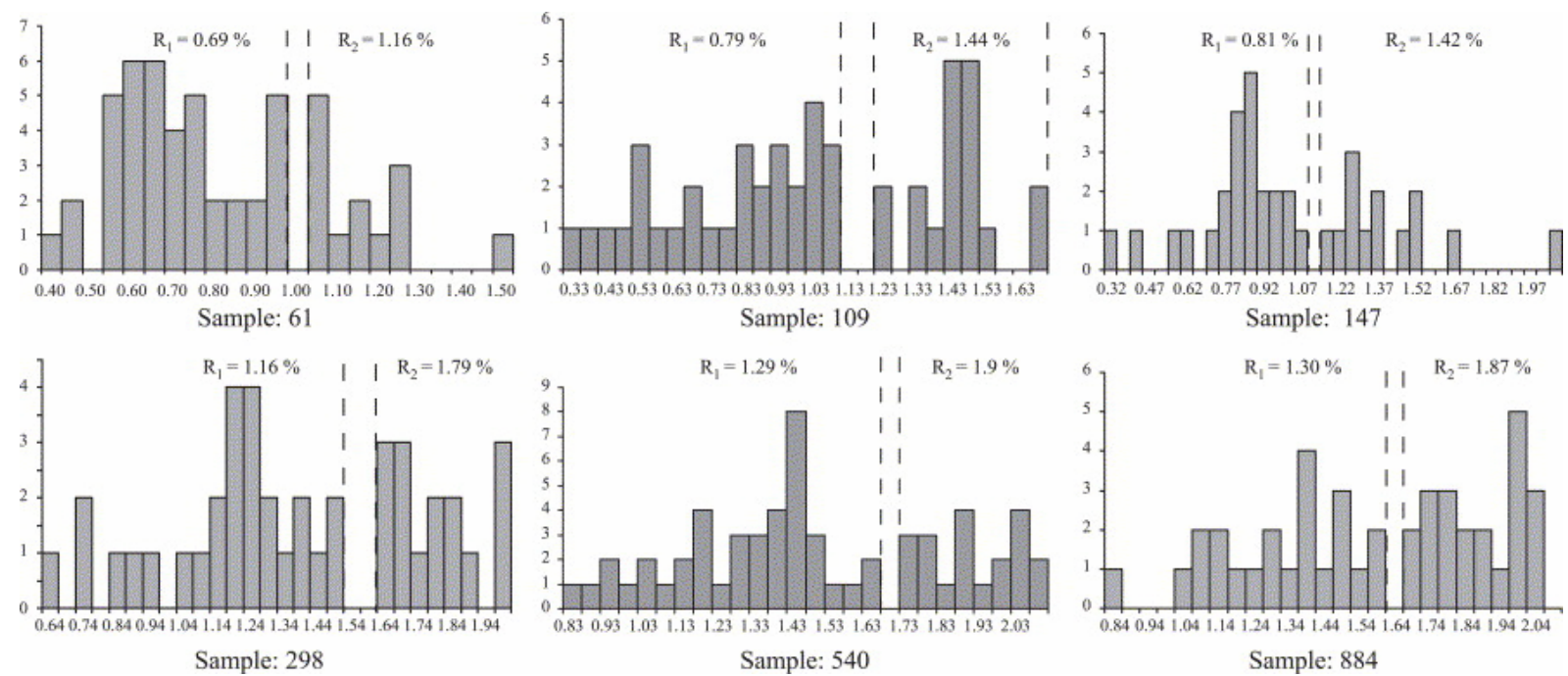

Fig. 6. Reflectance histograms indicating two vitrinite populations in MM-1 samples.

\section{Discussion}

Generally, two main approaches are used to determine reflectance data and consequently to distinguish autochthonous and recycled vitrinite. As illustrated above, the first approach consists of measuring random reflectance on 50-100 particles supposed to represent all the possible vitrinite group types present in the studied sample then differentiating these groups in reflectance vs. measurement frequency plots (Stach et al., 1982 and Barker and Pawlewicz, 1993). Usually, the group with the lowest reflectance is assumed to represent autochthonous vitrinite. However, there is a major risk of confusion with liptinite, caving mud, or lignite, which may also have a very low reflectance. In the second approach, reflectance measurements are made only on first-cycle or autochthonous particles recognized according to a particular morphology (nonrounded, relatively high length, wispy appearance; Lo, 1992) and a specific reflectance (low grey; Barker, 1996). However, all morphologic criteria defined in this second approach, especially the size and shape, are not specific to one category of vitrinite and can depend on hydrodynamic conditions encountered during the transport of particulate material to the deposition site.

In the present study, we used two main petrographic criteria to recognize autochthonous vitrinite particles. The first criterion (see Section 4.2) is related to the presence of telinite and its genetic relation with collotelinite. This criterion requires a reliable identification of macerals and on the in situ transformation of one type (telinite) of maceral in another one (collotelinite). The second criterion lies in the presence of pyrite denoting anoxic conditions in the depositional environmental. Such conditions are favourable to lignocellulosic organic matter gelification and thus vitrinite formation. Indeed, in oxic conditions, organic matter degradation mostly proceeds to fusinisation (Taylor et al., 1998). The presence of pyrite in inclusions in organic particles was one of the seven criteria used by Benedict et al. (1968) to discriminate nonoxidized from oxidized vitrinite particles in American coals. In a more general way, pyrite destruction is well known to occur previous to notable organic matter oxidation (Littke et al., 1991 and Petsch et al., 2000). Our observations on the absence of pyrite in recycled vitrinites are fully consistent with this statement. 
Nevertheless, it must be kept in mind that the occurrence of pyrite flamboids depends on several environmental factors, beginning with free iron availability in the medium. Such a lack must result in an absence of pyrite in the sediment and particularly in autochthonous vitrinite particles that must obviously not be interpreted in terms of recycling. This observation may certainly explain the absence of such inclusions observed in MM-1 well. In a similar way, telinite mainly characterises the organic matter immature stage and become rarer when rank increases. This progressive disappearance is related to the homogenisation of telinite particles, which progressively leaves place to more homogeneous collotelinite material.

It finally appears that the diagnostic criteria mainly depend on the particularity of the depositional environments and local coalification history. Thus, our observations fully illustrate the difficulty of standardising vitrinite recognizance diagnostic criteria because of the diversity of geological setting in sedimentary basin. However, for each studied sample, the best way to distinguish indigenous and recycled particles is to take into account complementary indications about depositional conditions and maturity level in sedimentary basin.

In addition to the difficulty of their identification, recycled particles pose several other problems related to the evolution of their reflectance during recycling and the subsequent reburial stage. In a previous work, it was admitted that, for recycled vitrinite, the reflectance value extrapolated from a linear $\log R_{\mathrm{o}}$ vs. depth plot to the sediment surface was equivalent to that acquired by this material previous to its recycling (Dow, 1977 and Alpern and Cheymol, 1978). In so doing, the authors admitted that vitrinite reflectance did not change during the whole of its remobilization history, i.e., the erosion of the primary host formation, the weathering of the $\mathrm{OM}$, the transportation of the particles to their new burial place, and in situ early diagenesis.

In addition, another common characteristic of recycled vitrinite is that it seems to evolve at a greater rate than autochthonous material with increasing burial. As first emphasized by Dow (1977) in his study of Texas Gulf Coast sediments, this can be evidenced in a log $R_{0}$ vs. depth plot by the greater slope of the regression line obtained from the reflectance of autochthonous material than that of the recycled one. This author explained tentatively the observed difference by the previous thermal history known by the recycled material. A similar trend was effectively also observed with our two sample sets from DN-2 and MM-1 wells. Comparable observations had also been made by Alpern and Cheymol (1978) when studying the lower Jurassic beds in the east of the Paris basin. According to reflectance values, these authors defined three vitrinite populations the reflectance of which increased progressively with depth. In order to determine the real maturity level of these sediments, they took the average reflectance of the first two groups of macerals having the lower reflectance.

The apparent new increase of reflectance of recycled vitrinite immediately from the reburial stage and its faster raise than that of autochthonous material during the subsequent diagenetic history both contradict the classical maximum paleotemperature concept according to which $R_{\mathrm{o}}$ is mostly or even totally controlled by temperature (e.g., Barker and Pawlewicz, 1994). This concept entails that any increase of recycled vitrinite $R_{0}$ supposes that the thermal conditions are then comparable to those reached at the peak of the previous diagenetic history. This 
requirement was nicely illustrated by Saxby et al. (1986). Indeed, by comparing thermal evolution of vitrinite in brown coal $(0.6 \%$ initial Ro) and brown Torbanite $(0.2 \%$ initial Ro), these authors demonstrated that vitrinite reflectance in brown coal remained globally constant during the first maturation stage until the vitrinite of both samples reached the same maturity level (i.e., $0.6 \%$ ); then, they increased in the same way. In other words, all things being taken equal between laboratory and field conditions, the reflectance of the already highly mature brown coal vitrinite only began to rise when the thermal energy level reached by heating in the laboratory was similar to that reached during the previous geological thermal stage. Thus, consistent with more or less empirical approaches (Karweil, 1956, Bostick, 1971 and Barker and Pawlewicz, 1994) and kinetic modeling (Burnham and Sweeney, 1989), the experiment of Saxby et al. (1986) verifies that temperature exerts the main control on vitrinite reflectance evolution, time intervening only as a secondary factor. From a more detailed point of view, two major phases are usually recognized in vitrinite evolution. The first phase $(0.2-0.7 \%)$ is where vitrinite increases slowly because of the low appearance of polycyclic aromatic molecules (Carr and Williamson, 1990 and Suggate, 1998). The second phase (0.7-3\%) results in the rapid rise in the reflectance value attributed to an abundance of polycyclic aromatic molecules.

Two main factors are to be taken into account when considering the new evolution of recycled vitrinites: their previous thermal evolution and recycling impact. Exposure of vitrinite to the atmosphere during host rock erosion and further particle transportation to a new burial place necessarily results in extensive weathering. The impact of this process on the physical and chemical properties of the OM is very complex (Chang and Berner, 1999; and references therein). Ultimate analysis shows that it leads to a loss of hydrogen and a gain of oxygen (expressed by $\mathrm{H} / \mathrm{C}$ and $\mathrm{O} / \mathrm{C}$ ratios as well as by $\mathrm{HI}$ and OI Rock-Eval indexes; Lo and Cardott, 1995). From a structural point of view, its provokes the loss of aliphatic moieties and the formation of carbonyl and other oxygenated functional groups (Lo and Cardott, 1995, Marchioni, 1983 and Copard, 2002). Nevertheless, maybe except when it is very extensive, it does not affect the aromatic nuclei that constitute the kerogen basic structural units, the socalled "BSUs" (Copard, 2002). There is seemingly no general agreement on the impact of weathering on vitrinite reflectance. However, recent work has shown that extensive weathering of low mature (Lo and Cardott, 1995) as well as of highly mature coals (Copard et al., 2002) does not cause any significant change of vitrinite reflectance (except those measured on fringes existing on the edges of oxidised vitrinite particles) despite considerable compositional changes (Fig. 7). 


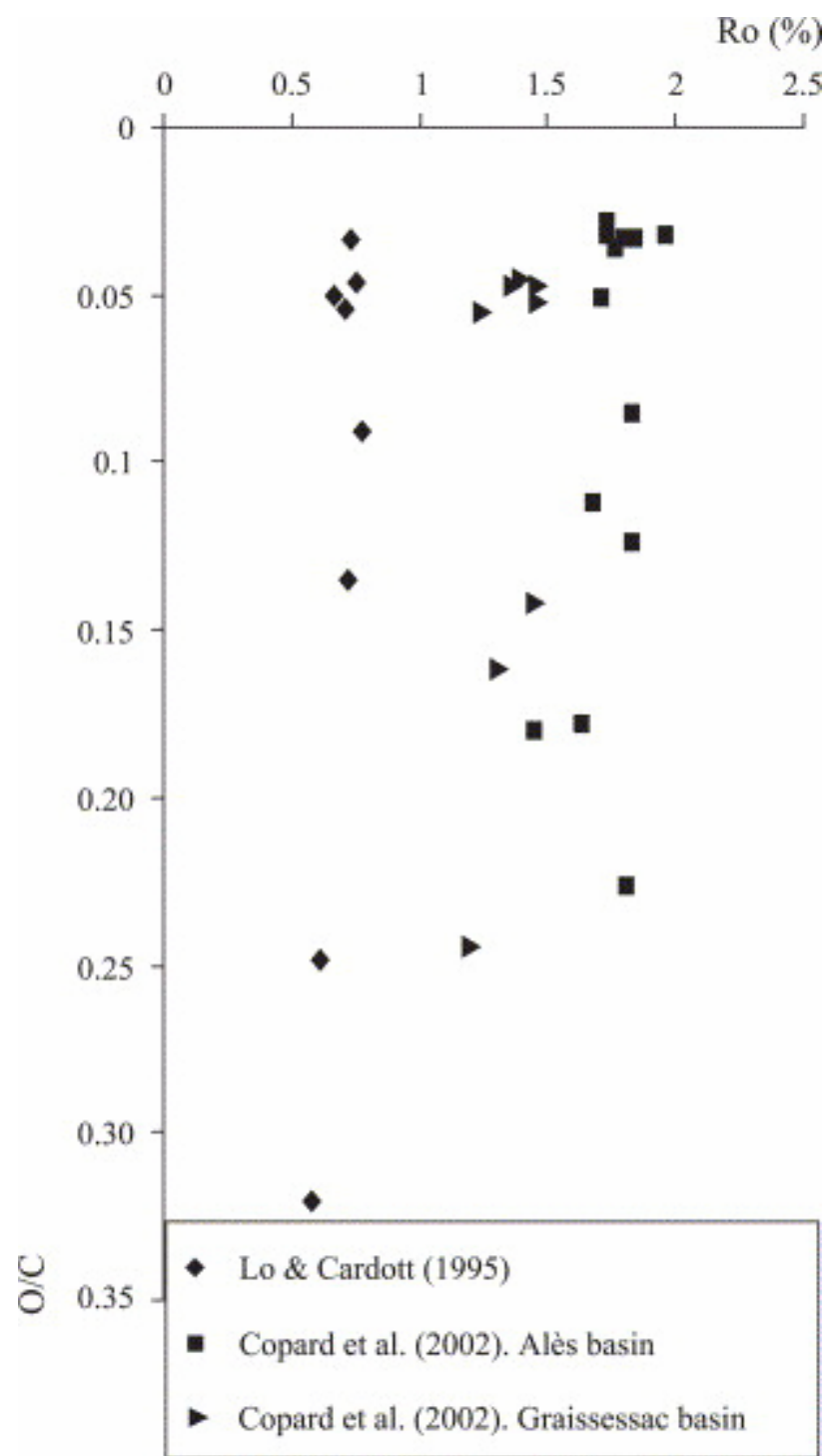

Fig. 7. Reflectance $\left(R_{0}\right)$ vs. O/C atomic ratio. Note the absence of marked reflectance change with weathering.

In this respect, the distinction of low and mature coals is important because, at the difference of the formers, the latter also undergoes a significant increase of their Rock-Eval Tmax value with increasing weathering intensity (Copard et al., 2002). As already mentioned above, a detailed analysis of series of highly mature coals revealed that weathering affects the functional groups peripheral to the polyaromatic nuclei that constitute the basic structural units (BSUs) of the coal structure but not the nuclei themselves. These observations are important because they provide strong support to the postulate of the preservation of the reflectance of vitrinites during recycling. This postulate was admitted and applied by Dow (1977) when estimating the original reflectance of recycled material by extending the intercept of $R_{\mathrm{o}}$ vs. depth plot to the sediment surface. The considerable chemical changes undergone by vitrinites in the course of their oxidation opposed to the preservation of their aromatic nuclei also bring some logical support in favour of this postulate. In addition, these dual effects also provide some ideas in an attempt to explain the rise of the reflectance of recycled material immediately from the beginning of its new burial stage, i.e., in the low-temperature conditions that exist near the sea bottom. The rejuvenation provoked by weathering with the formation of new oxygenated chemical 
groups on the border of the aromatic nuclei of BSUs may confer them a new reactivity and thus the susceptibility to evolve in low-temperature conditions. Reversibly, during the subsequent burial stage, the original preservation of already well-developed aromatic moieties might limit the rate of development of the new structural organisation, thus explaining why recycled particles mature more slowly that autochthonous ones.

According to Murchison et al. (1985), it is clear that the reflectance evolution path of recycled particles is located between those of the vitrinite and inertinite groups or more precisely between the hydrogen-rich and hydrogen-poor collotelinite and inertinite, respectively (Fig. 8). During recycling, exposure to oxidation for variable durations progressively changes vitrinite into inertinite-like material which does not obey the same kinetic laws as indigenous vitrinite. This assumption is consistent with observations of Kaegi (1985) who noted that low-temperature oxidation converts pseudovitrinite into oxyvitrinite which is practically inertinite debris. Later, Bustin and Guo (1999) suggested that vitrinite and inertinite particles affected by the same thermal conditions show a subparallel increase in reflectance. In a comparable way, Gauthier et al. (1985) also observed a simultaneous increase of autochthonous and allochthonous vitrinite and inertinite particles in response to a hydrothermal event that affected the host carbonate formation. All these observation led us to suggest that no maceral is completely inert and thus still present potentialities for transformation during further thermal evolution.

Recycled vitrinite (and inertinite) particles still present a reactivity that determines their transformation in new thermal conditions. Nevertheless, the initial reflectance of these recycled materials reflects previous burial history and consequently cannot be used for thermal maturity assessment of their new host formation. As exemplified by the only slight reflectance changes that affect coals during extensive weathering, the transformation potentiality of such materials which determined their reflectance changes rely on unknown factors that most certainly have very little to do with their chemical composition, unless in an indirect (i.e., nonproportional) way. Assuming that inert particles have no transformation potentialities, then recycled vitrinites can be seen as transitional material or moderately oxidized debris when compared to inertinite. Then, the confrontation of our observations to those previously made by Dow (1977) and Alpern and Cheymol (1978) led us to admit the existence of various groups of recycled or oxidized particles between inertinite and vitrinite macerals, the starting chemical composition of these materials mostly depending on the maturation level they reached during their previous burial history.

All this explanation is only tentative, the comparison between inertinite and vitrinite reflectance evolution remaining very complex. For example, some electron microprobe studies demonstrated that vitrinite having same reflectance as inertinite did not necessarily have the same ultimate chemistry (Mastalerz and Bustin, 1993). At least, this observation confirms that reflectance does not follow a single and rather simple factor 


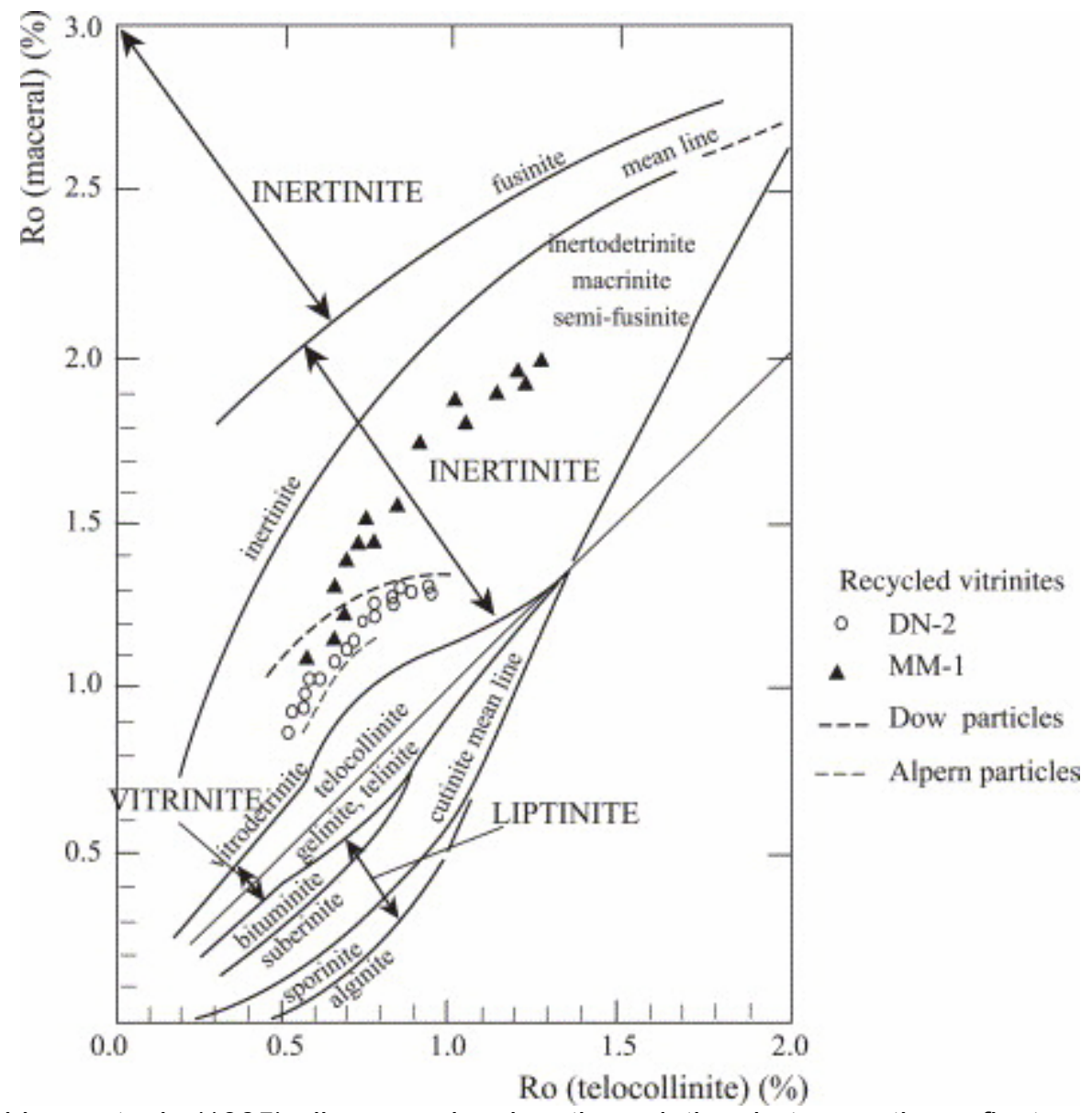

Fig. 8. Murchison et al. (1985) diagram showing the relation between the reflectance of various maceral groups relative to that of vitrinite. The recycled vitrinite reflectance pathway is located between those of inertinite and primary vitrinite. With increasing maturity, the reflectance of recycled vitrinite tends to converge to that of autochthonous vitrinite.

\section{Conclusions}

The discussion of diagnostics criteria to identify recycled vitrinite and the characterisation of their optical properties during the various stages of their evolution has shown that

(1) Because vitrinite is a large and complex family according to chemical composition, depositional environment, and maturation level, the attempt of standardisation is limited by the particularity of each geological context. However, in a favourable geological context, the genetic relationship between telinite and collotelinite coupled to the presence of pyrite inclusions in primary vitrinite appear as reliable identification criteria.

(2) Mostly based on reflectance evolution, recycled vitrinites appear as transitional materials between autochthonous vitrinite and inertodetrinite. Their chemical and structural characteristics are related to their previous thermal evolution and their subsequent oxidation during the weathering stage. Their reflectance evolution which 
tends to mimic that of inertinite particles does not rely anymore to the thermal maturity trend followed by autochthonous particles.

(3) Finally, this study points out the complexity in reflectance characteristic of natural organic materials. More than to chemical composition, reflectance changes probably depend on the "transformation capacity" of each particle. This latter parameter is supposed to depend both on the chemical and structural composition of the materials at a given stage of geological evolution. Then, the inert state (e.g., for oxidised material) should be reached when there is no more transformation capacity.

\section{Acknowledgements}

The authors would like to thank A.O. Wane and J. Medou from the Senegalese Petroleum Corporation for allowing us to access the data and collect the samples. They are grateful to $M$. Hatton and D. Keravis for technical assistance and to $M$. Boussafir for fruitful discussions. Valuable review comments on the manuscript were received from Dr. Fariborz Goodarzi and an anonymous reviewer.

\section{References}

Alpern and Cheymol, 1978 B. Alpern and D. Cheymol, Réflectance et fluorescence des organoclastes du Toarcien du bassin de Paris en fonction de la profondeur et de la température, Rev. Inst. Fr. Pét. 33 (1978) (4), pp. 515-535.

Barker, 1996 C.E. Barker, A comparison of vitrinite reflectance measurements made on whole-rock and dispersed organic matter concentrate mounts, Org. Geochem. 24 (1996), pp. 251-256.

Barker and Pawlewicz, 1993 C.E. Barker and M.J. Pawlewicz, An empirical determination of the minimum number of measurements needed to estimate the mean random vitrinite reflectance of disseminated organic matter, Org. Geochem. 20 (1993), pp. 643-651.

Barker and Pawlewicz, 1994 C.E. Barker and M.J. Pawlewicz, Calculation of vitrinite reflectance from thermal histories and peak temperatures In: P.K. Mukhopadhyay and W.G. Dow, Editors, ACS Symposium Series 570, Vitrinite Reflectance as a Maturity Parameter, Applications and Limitations (1994), pp. 216-229 Chap. 14.

Benedict et al., 1968 L.G. Benedict, R.R. Thompson, J.J. Shigo and R.P. Aikman, Pseudovitrinite in Appalachian coking coals, Fuel 47 (1968), pp. 125-143.

Bostick, 1971 N.H. Bostick, Thermal maturation of clastic organic particles as an indicator of contact and burial metamorphism in sedimentary rocks, Proc. 2nd Geosc. Man., Am. Ass. Stratigr. Palynologist Vol. 3 (1971), pp. 83-92.

Burnham and Sweeney, 1989 A.K. Burnham and J.J. Sweeney, A chemical kinetic model of vitrinite maturation and reflectance, Geochim. Cosmochim. Acta 53 (1989), pp. 2649-2657. 
Bustin and Guo, 1999 R.M. Bustin and Y. Guo, Abrupt changes (jumps) in reflectance values and chemical composition of artificial charcoals and inertinite in coals, Int. J. Coal Geol. 38 (1999), pp. 237-260.

Carr and Williamson, 1990 A.D. Carr and J.E. Williamson, The relationship between aromaticity, vitrinite reflectance and maceral composition of coals: implications for the use of vitrinite reflectance as a maturation parameter, Org. Geochem. 16 (1990), pp. 313-323.

Chang and Berner, 1999 S. Chang and R.A. Berner, Coal weathering and the geochemical carbon cycle, Geochim. Cosmochim. Acta 63 (1999), pp. 3301-3310.

Copard, 2002 Copard, Y., 2002. Altération diagénétique et post-diagénétique (thermicité, oxidation) des charbons carbonifères du Massif Central français (SaintEtienne, Graissessac et autres lieux) thesis, University of Orléans, 305 pp.

Copard et al., 2002 Y. Copard, J.R. Disnar and J.F. Becq-Giraudon, Erroneous maturity assessment given by $T_{\max }$ and $\mathrm{HI}$ Rock-Eval parameters on highly mature weathered coals, Int. J. Coal Geol. 49 (2002), pp. 57-65.

Disnar et al., 1997 J.R. Disnar, F. Marquis, J. Espitalié, I. Barsony, S. Drouet and D. Giot, Géochimie organique et reconstitution de l'histoire thermique et tectonosédimentaire de la marge ardéchoise (programme GPF; France), Bull. Soc. Géol. Fr. 168 (1997), pp. 73-81.

Dow, 1977 W.G. Dow, Kerogen studies and geological interpretation, J. Geochem. Explor. 7 (1977), pp. 79-99.

Dow and O'Connor, 1980 W.G. Dow and D.I. O'Connor, Kerogen maturity and type by reflected light microscopy applied to petroleum exploration In: F.L. Staplin, Editors, How to assess organic maturation and paleotemperatures:S.E.P.M. Short Course vol. 7 (1980), pp. 133-157.

Durand et al., 1986 B. Durand, B. Alpern, J.L. Pittion and B. Pradier, Reflectance of vitrinite as a control of thermal history of sediments In: J. Burrus, Editors, Thermal Modelling in Sedimentary Basins, Technip, Paris (1986), pp. 441-474.

Elmi et al., 1991 S. Elmi, G. Dromart, D. Giot, H. Manivit, B. Courtinat, C. Ruget, M. Steinberg, F. Depeche, D. Fauconnier, S. Gargi, R. Rauscher, V. Reale and M. Schuller, La succession stratigraphique (Trias-Jurassique) du sondage Balazuc $n^{\circ} 1$ (Programme géologie profonde de la France, Ardèche): un exemple d'épaississement remarquable le long d'une marge tectonique contrôlée, C. R. Acad. Sci., Paris 312 (1991), pp. 747-754.

Gauthier et al., 1985 B. Gauthier, J.R. Disnar, J.C. Macquar and J. Trichet, Pétrographie de la matière organique des séries carbonatées liasiques du gîte $\mathrm{Zn}$ $\mathrm{Pb}$ de Trèves (Gard, France). Implications génétiques, C. R. Acad. Sci. Paris Sér. II 300 (1985), pp. 413-416. 
Goodarzi et al., 1994 F. Goodarzi, L. Snowdon, T. Gentzis and D. Pearson, Petrological and chemical characteristics of liptinite-rich coals from Alberta, Canada, Mar. Pet. Geol. 11 (1994), pp. 307-319.

Iglesias et al., 2000 M.J. Iglesias, A. Jimenez, J.C. del Rjo and I. Suarez-Ruiz, Molecular characterisation of vitrinite in relation to natural hydrogen enrichment and depositional environment, Org. Geochem. 31 (2000), pp. 1285-1299.

International Committee of Coal Petrology, 1971 International Committee of Coal Petrology, International Handbook of Coal Petrography (2nd ed.), CNRS, Paris (1971).

International Committee of Coal Petrology, 1998 International Committee of Coal Petrology, The new vitrinite classification (ICCP System 1994), Fuel 77 (1998), pp. 349-358.

Jimenez et al., 1994 A. Jimenez, F. Laggoun-Defarge, M.J. Iglesias, J.G. Prado and I. Suarez-Ruiz, Significance of the resinization and oil impregnation processes in reflectance suppression of the vitrinite (abstract), ICCP News 10 (1994), pp. 10-11.

Jones et al., 1971 J.M. Jones, D.G. Murchison and S.A. Saleh, Variation of vitrinite reflectivity in relation to lithology, Advances in Organic Geochemistry, Pergamon Press, Oxford (1971), pp. 601-612.

Kaegi, 1985 D.D. Kaegi, On the identification and the origin of pseudovitrinite, Int. J. Coal Geol. 4 (1985), pp. 309-319.

Kalkreuth, 1982 W. Kalkreuth, Rank and petrographic composition of selected Jurassic-lower cretaceous coals of British Columbia, Canada, Bull. Can. Pet. Geol. 30 (1982), pp. 112-139.

Karweil, $1956 \mathrm{~J}$. Karweil, Die metarmorphose der kohlen vom standpunky der physikalischen chemie, Z. Dtsch. Geol. Ges. 107 (1956), pp. 132-138.

Lafargue et al., 1998 E. Lafargue, F. Marquis and D. Pillot, Rock-Eval 6 applications in hydrocarbon exploration, production, and soil contamination studies, Rev. Inst. Fr. Pét. 56 (1998), pp. 421-437.

Liger and Roussel, 1979 J.L. Liger and J. Roussel, Etude gravimétrique du bassin côtier profond du Sénégal, Rev. Géol. Dyn. Géogr. Phys. 21 (1979) (5), pp. 411-419.

Littke et al., 1991 R. Littke, U. Klussmann, B. Kroos and D. Leythaeuser, Quantification of loss of calcite, pyrite, and organic matter due to weathering of Toarcian black shales and affects on kerogen and bitumen characteristics, Geochim. Cosmochim. Acta 55 (1991), pp. 3369-3378.

Lo, 1992 H.B. Lo, Identification of indigenous vitrinites for improved thermal maturity evaluation, Org. Geochem. 18 (1992), pp. 359-364. 
Lo and Cardott, 1995 H.B. Lo and B.J. Cardott, Detection of natural weathering of upper McAlester coal and Woodford Shale Oklahoma, USA, Org. Geochem. 22 (1995), pp. 73-83.

Malinconico, 2000 M.L. Malinconico, Using reflectance crossplots and rotational polarization for determining first-cycle vitrinite for maturation studies, Int. J. Coal Geol. 43 (2000), pp. 105-120.

Marchioni, 1983 D.L. Marchioni, The detection of weathering in coal by petrographic, rheologic and chemical methods, Int. J. Coal Geol. 2 (1983), pp. 231-259.

Mastalerz and Bustin, 1993 M. Mastalerz and R.M. Bustin, Variation in maceral chemistry within and between coals of varying rank: an electron microprobe and micro-Fourier transform infrared investigation, J. Microsc. 171 (1993), pp. 153-166.

Mukhopadhyay, 1994 P.K. Mukhopadhyay, Vitrinite reflectance as maturity parameter: petrographic and molecular characterisation and its applications to basin modeling In: P.K. Mukhopadhyay and W.G. Dow, Editors, Vitrinite Reflectance as a Maturity Parameter. Applications and Limitations, ACS Symposium Series No. 570, American Chemical Society, Washington, DC (1994), pp. 1-24.

Murchison et al., 1985 D.G. Murchison, A.C. Cook and A.C. Raymond, Optical properties of organic matter in relation to thermal gradients and structural deformation, Philos. Trans. R. Soc. Lond., A 315 (1985), pp. 157-486.

Nzoussi et al., 2003 M.P. Nzoussi, J.R. Disnar and F. Laggoun-Défarge, Organic matter characteristics of Cenomanian-Turonian source rocks: implications for petroleum and gas exploration onshore Senegal, Mar. Pet. Geol. 20 (2003), pp. 411427.

Pearson and Murchison, 1989 J. Pearson and D.G. Murchison, Influence of a sandstone washout on the properties of an underlying coal seam, Fuel 69 (1989), pp. 251-253.

Petsch et al., 2000 S.T. Petsch, R.A. Berner and T.I. Eglinton, A field study of the chemical weatrhering of ancient sedimentary organic matter, Org. Geochem. 31 (2000), pp. 475-487.

Price and Barker, 1985 L.C. Price and C.E. Barker, Suppression of vitrinite reflectance in amorphous rich kerogen-a major unrecognized problem, J. Pet. Geol. 8 (1985), pp. 59-84.

Raymond and Murchison, 1991 A.C. Raymond and D.G. Murchison, Influence of exinitic macerals on the reflectance of vitrinite in Carboniferous sediments of the Midland Valley of Scotland, Fuel 70 (1991), pp. 155-161.

Robert, 1985 P. Robert, Histoire géothermique et diagenèse thermique, Bull. Centre Rech. Explo.-Prod. vol. 8, Elf-Aquitaine (1985), pp. 133-160. 
Scott, 2002 A.C. Scott, Coal petrology and the origin of coal macerals: a way ahead?, Int. J. Coal Geol. 50 (2002), pp. 119-134.

Saxby et al., 1986 J.D. Saxby, A.J.R. Bennet, J.F. Corcoran, D.E. Lambert and K.W. Riley, Petroleum generation simulation over six years of hydrocarbon formation from torbanite and brown coal in subsiding basin, Org. Geochem. 9 (1986), pp. 69-81.

Stach et al., 1982 E. Stach, M.T. Mackowsky, M. Teichmüller, G.H. Taylor, D. Chandra and R. Teichmüller, Stach's Textbook of Coal Petrology, Gebrüder Borntraeger, Berlin (1982) 535 pp..

Suggate, 1998 R.P. Suggate, Relations between depth of burial, vitrinite reflectance and geothermal gradient, J. Pet. Geol. 21 (1998), pp. 5-32.

Taylor et al., 1998 G.H. Taylor, M. Teichmüller, A. Davis, C.F.K. Diessel, R. Littke and P. Robert, Organic Petrology, Gebrüder Borntraeger, Berlin (1998) 704 p..

Teichmüller, 1982 M. Teichmüller, Rank determination on sedimentary rocks other than coal In: E. Stach, M.-Th. Mackowsky, M. Teichmüller, G.H. Taylor, D. Chandra and R. Teichmüller, Editors, Stach's Textbook of Coal Petrology, GebrüderBontraeger, Berlin (1982), pp. 361-371.

Tissot and Welte, 1984 B.P. Tissot and D.H. Welte, Petroleum Formation and Occurrence, Springer-Verlag, Berlin (1984) 699 pp..

Villeneuve and Da Rocha Arajou, 1984 M. Villeneuve and P.R. Da Rocha Arajou, La stratigraphie du bassin paléozoïque de Guinée (Afrique de l'Ouest), Bull. Soc. Géol. Fr. 32 (1984), pp. 29-40.

Vinchon et al., 1996 C. Vinchon, D. Giot, F. Orsag-Sperber, F. Arbey, J. Thibieroz, P. Cros, D. Jeannette and J.P. Sizun, Changes in reservoir quality determined from the diagenetic evolution of Triassic and Lower Lias sedimentary successions (Balazuc borehole, Ardèche, France), Mar. Pet. Geol. 13 (1996), pp. 685-688. 